\title{
EVIDENCE OF SELF-FERTILIZATION IN CERTAIN SPECIES OF BARNACLES
}

\author{
By H. Barnes \\ The Marine Station, Millport \\ and D. J. Crisp \\ Marine Biology Station, University College of North Wales, Bangor
}

Isolated individuals of certain species of cirripedes are known to remain unfertilized at the time when the majority of contiguous individuals are carrying egg masses. From a very large number of observations on both Balanus balanoides (L.) and Elminius modestus Darwin (Crisp, 1950, 1956) there remains little doubt that in these two species copulation is necessary before eggs are brought into the mantle cavity where they are fertilized. Though fewer field observations have been made, Balanus crenatus Bruguière appears to behave similarly, isolated specimens grown on raft-exposed panels never bearing fertilized egg masses (Crisp, 1950; Barnes, unpublished observation). B. balanus (L.) (=B. porcatus da Costa) is also in all probability an obligatory cross-fertilizing hermaphrodite, though the available evidence does not exclude the possibility of self-fertilization in rare instances (Crisp, 1954; Barnes \& Barnes, 1954).

It appeared possible to one of us that obligatory cross-fertilization might be the rule for all cirripedes, and some ecological consequences of this were pointed out by Crisp (1950). However, we have independently come to the conclusion that certain species, though they may normally cross-fertilize whenever this is possible, can also bear apparently viable egg masses without copulation having taken place.

\section{EVIDENCE FOR SeLF-FERTILIZATION IN CHTHAMALUS STELLATUS}

Under natural conditions it is exceedingly difficult to find an individual of Elminius modestus, Balanus balanoides or B. crenatus fertilized when separated by a distance of $5 \mathrm{~cm}$ or more from its neighbour. This critical distance represents the maximum extension of the penis. Since the possibility usually exists that another individual might be carried into the vicinity of an experimentally isolated barnacle on the shell of a wandering mollusc, any rare exception may be attributed to such an accident. In some circumstances such a remote possibility may be entirely excluded, as for example in the case of Elminius modestus which has been shown to be cross-fertilizing by carrying out experiments on individuals 
introduced into an area that was not at the time populated by this species (Crisp, 1956). Nevertheless, even when the possibility of individuals approaching accidentally is not entirely excluded, the artificially isolated individuals are almost invariably found to be without fertilized egg masses in these three species. It is therefore reasonable to conclude that if in such an experiment with another species a significant proportion of isolated individuals become gravid, the majority of them, if not all, must have deposited their eggs in the mantle cavity without having copulated with another individual.

Table I. Self-Fertilization in Chthamalus Stellatus

\begin{tabular}{|c|c|c|c|c|c|}
\hline Date & Locality & $\begin{array}{l}\text { Distance } \\
\text { between } \\
\text { individuals } \\
(\mathrm{cm})\end{array}$ & $\begin{array}{c}\text { No. of } \\
\text { individuals } \\
\text { in sample }\end{array}$ & $\begin{array}{l}\text { Percentage } \\
\text { fertilized }\end{array}$ & $\begin{array}{l}\text { Percentage } \\
\text { fertilized } \\
\text { among } \\
\text { controls }\end{array}$ \\
\hline 24. vi. 54 & Millport & $\begin{array}{r}2.5-5.0 \\
5.0-7.5 \\
7.5-10.0 \\
>10.0\end{array}$ & $\begin{array}{l}20 \\
20 \\
20 \\
20\end{array}$ & $\left.\begin{array}{l}45 \\
40 \\
40 \\
45\end{array}\right)$ & 96 \\
\hline I2. vii. 54 & Millport & $\begin{array}{r}2.5-5.0 \\
5.0-7.5 \\
7.5-10.0 \\
>10.0\end{array}$ & $\begin{array}{l}20 \\
20 \\
20 \\
20\end{array}$ & $\left.\begin{array}{l}55 \\
60 \\
50 \\
32\end{array}\right\}$ & 48 \\
\hline 4. viii. 54 & Millport & $\begin{array}{r}2.5-5.0 \\
5.0-7.5 \\
7.5-10.0 \\
>10.0\end{array}$ & $\begin{array}{l}20 \\
20 \\
20 \\
20\end{array}$ & $\left.\begin{array}{l}55 \\
50 \\
60 \\
30\end{array}\right\}$ & 55 \\
\hline 8. vi. 52 & Aberffraw & $\begin{array}{r}I-3 \\
3-5 \\
5\end{array}$ & $\begin{array}{l}57 \\
20 \\
13\end{array}$ & $\begin{array}{l}53 \\
50 \\
23\end{array}$ & $\begin{array}{l}57 \\
52 \\
28\end{array}$ \\
\hline 20. vii. 52 & Aberffraw & $\begin{array}{l}I-3 \\
3-5 \\
>5\end{array}$ & $\begin{array}{l}\text { I0 } \\
\text { I4 } \\
37\end{array}$ & $\begin{array}{l}80 \\
86 \\
41\end{array}$ & $\begin{array}{l}70 \\
71 \\
50\end{array}$ \\
\hline 22. vi. 52 & Black Rock` nr. Portmadoc & $>7$ & I4 & 36 & 43 \\
\hline 7. vi. 53 & New Brighton* & $>10$ & 50 & I8 & 74 \\
\hline 29. vi. 53 & New Brighton* & $\begin{array}{r}2-5 \\
>10\end{array}$ & $\begin{array}{r}\text { ro } \\
8\end{array}$ & $\begin{array}{r}20 \\
0\end{array}$ & $\begin{array}{r}100 \\
90\end{array}$ \\
\hline 5. vii. 53 & Aberffraw & $>$ I0 & 7 & 57 & 55 \\
\hline
\end{tabular}

* Naturally occurring individuals which were not experimentally isolated.

This conclusion applies with special force in the case of Chthamalus growing sparsely near high-water mark in areas where it is not very abundant, for Chthamalus is only found on mollusc shells when it is extremely common on the rocks throughout the intertidal zone.

Table I gives the percentage of individuals carrying egg masses, compared with the percentage found among a large number of controls gathered from the same piece of rock at the same level. Control individuals were in all cases in physical contact with one or more other specimens of mature size. Great care is necessary in choosing control individuals to ensure that they are drawn from the same type of environment since tide level, aspect, and access to surf can profoundly influence the fecundity. At Millport, the results refer to 
naturally isolated individuals of mature age. In the North Wales experiments the individuals were in most cases isolated by removing all others within a given distance prior to April, since breeding does not start until May, although in some cases naturally isolated individuals were taken in the sample.

Table I clearly shows that while at some places isolated individuals appear to be just as fertile as contiguous ones, in other instances, as for example at New Brighton, there is evidence that isolated individuals have not been fertilized to the same extent as contiguous individuals.

There is some evidence to show that oviposition may be delayed in isolated as compared with contiguous specimens. The observations at Aberffraw on 9 June 1952 were made early in the breeding season at a time when the first brood was developing in the mantle cavity. Although there was only a small percentage fertilized in both isolated and contiguous individuals, the latter were at a slightly later stage of development. Thus the percentage of the population which had reached a given stage of development was always greater in the contiguous than the isolated populations. Similarly, on 29 June 1953 at New Brighton, where a very great disparity existed between isolated and contiguous individuals, the latter had just produced a second brood and the embryos were all in an early stage of development. At Millport, where conditions are less favourable for this warm water species, the percentage fertilized in June was much higher in the contiguous individuals. The evidence as a whole is consistent with the view that oviposition may take place without insemination by another individual if the ovaries remain unfertilized for some time after reaching a ripe condition. It follows, therefore, that unless these eggs develop parthenogenetically, self-fertilization must take place.

In addition to these observations, fertilized isolated individuals have also been met with from time to time. These are more obvious in areas where the species is not very abundant, as in the north of Scotland. Examples of apparently self-fertilized individuals have been seen at W. Loch Tarbert, Argyll I August 1953 at about M.H.W.S.T.L., at 'the spur' west of Dunnet Head, Caithness, and by Dr A. J. Southward (personal communication) at Stenness, Esha Ness, Shetland. Individuals grown in isolation on raftexposed panels at Millport have also been found to contain ripe egg masses.

\section{VIABILITY OF EGGS WHICH ARE NOT CROSS-FERTILIZED}

Eggs produced without copulation appear to be less viable than normally fertilized eggs. Occasionally in egg masses of many species, groups of ova may be found which do not develop, but remain in the primitive unsegmented condition. Such eggs are probably unfertilized and are voided with the hatched nauplii when the latter are fully developed. It was noticed that a considerable proportion, sometimes as many as half, of the egg masses from isolated individuals contained unsegmented ova together with developing ova. 
In other cases abortive development took place, giving rise to segmented eggs with an abnormal appearance. For example, certain of the eggs examined from isolated individuals collected at Aberffraw on 8 June 1952 were difficult to classify as a stage in normal development, and one pair of egg masses appeared to be decomposing. It is therefore possible that the earlier state of development of broods from isolated individuals may not indicate later oviposition, but be due to abnormally slow development. Further evidence supporting this hypothesis is that at Millport during the late summer, whilst all stages of embryos were found in contiguous individuals indicating the development of successive broods in the population, only late stages were found in the isolated individuals. Slow development in the latter would prevent a further generation from being developed since eggs are not brought into the mantle cavity, even when ripe, in the presence of an earlier brood Crisp \& Davies, 1955).

Nevertheless, viable nauplii can be produced by isolated individuals, and indeed in every observation at Aberffraw recorded in Table I, and in the observation at Black Rock, at least one isolated individual contained nauplii which were fully developed and able to hatch.

At Millport undeveloped and degenerate egg masses in the mantle cavities of isolated individuals appear to be common earlier in the breeding season. In the early summer most of the eggs in the mantle cavities of isolated individuals were incompletely developed and in many cases the whole egg mass had begun to degenerate in situ; on being touched with a needle the egg mass broke down into an oily suspension of tissue. This is perhaps related to the fact that in such regions where the species is approaching its limit of distribution, only in late summer are the environmental conditions suitable for the species to reproduce. Thus even the early broods developed in contiguous individuals, although giving apparently normal nauplii which on teasing out will swim actively, do not give rise to any shore settlement. However, the broods produced from isolated individuals in the late summer appear completely normal; the nauplii hatch readily and swim vigorously. Similar temperature conditions apply in the Isle of Man, where the settlement of Chthamalus is confined to a period in late summer or autumn (Southward \& Crisp, I956).

The efficiency of self-fertilization also appears to be less than that of crossfertilization as regards the number of normal embryos produced. Counts of normal embryos in isolated and contiguous individuals of several size groups show a greater mean number $(t$-test) in the latter.

\section{Oviposition IN THE DRY STATE}

While in the dry state Chthamalus stellatus remains closed and does not protrude either the cirri or the penis. Copulation is therefore impossible under these conditions. However, there appears to be no reason why ovi- 
position should not occur, provided that copulation were not a necessary stimulus, just as moulting can take place with the shell closed (Darwin, I854). A number of stones covered with Chthamalus were stored in a moist warm place and sampled from time to time to determine the stage of development of the embryos. The egg masses developed normally, the earlier stages disappearing progressively from the population with the passage of time. Development was completed in I $5-16$ days at $18-20^{\circ} \mathrm{C}$ and in $2 \mathrm{I}-24$ days at $14-15^{\circ} \mathrm{C}$. The initial divisions of ova to form a blastoderm covering the yolk cell (stage 4 , see Crisp, I954) normally occupy less than $15 \%$ of the total time of development. Occasionally such stages were found long after this period had elapsed. In one individual egg masses at the eight cell stage (stage 3 ) were found in addition to fully developed egg masses 9 days after the eggs had been maintained at $18^{\circ} \mathrm{C}$ out of water. In another two, egg masses with blastoderm covering an undivided or partially divided yolk cell (stage 4-5) were found I4 days after the eggs had been maintained out of water at a temperature of $15^{\circ} \mathrm{C}$. In all three instances the eggs appeared to be healthy. These occurrences were exceptional and did not invalidate conclusions on rate of development being drawn from the experiment. Unless the rate of development can be greatly reduced by some factor other than temperature (e.g. water loss or oxygen lack) the conclusion must be drawn that oviposition in the dry state may occur under such conditions.

\section{EVIDENCE FOR SELF-FERTILIZATION IN OTHER SPECIES}

Single specimens of Verruca stroemia on shells of Modiolus are often dredged from Beaumaris bay. These apparently isolated specimens have been found on several occasions to contain developing egg masses. The shells of Modiolus are very sparsely scattered over the sea bed in this area (Baird, private communication) and the possibility of two individuals on separate shells lying close together must be very small. At Millport, Verruca stroemia gives one brood each year; fertilization takes place in late December and early January; the nauplii are shed in late February and early March, a little before those of Balanus balanoides and B. crenatus. Isolated and contiguous individuals on stones collected at extreme low water were examined for egg masses. By mid-January all individuals contained developing egg masses. There was little trace of any degeneration in those from isolated individuals, but eggs showing delayed development were often found with normally developing embryos in the same animal. This again suggests that cross-fertilization is more efficient. By mid-February some actively swimming nauplii could be obtained from most individuals. There was no apparent difference between nauplii derived from isolated and from contiguous barnacles. Further, barnacles which had been isolated by $5 \mathrm{~cm}$ and maintained on a raft for many months contained ripe egg masses with normal embryos. 
Balanus perforatus is a large intertidal species with a thick calcareous base which remains if an individual dies or is knocked off. Consequently, if an individual appears isolated it is easy to check whether another, no longer present, had formerly occupied a site sufficiently close to it for cross-fertilization. The species is rarely found on the shells of littoral molluscs. In parts of north Devon individuals isolated by a distance of $10 \mathrm{~cm}$ or more may be found in the same locality as groups of three or four together.

Table II gives the results of an investigation on a reef at Saunton Sands, North Devon. There is no doubt that in mid-August, when the observations were made, individuals situated more than $10 \mathrm{~cm}$ from each other not only can carry egg masses, but also are as fertile as contiguous specimens. However, the embryos of individuals grouped together were generally in a more advanced state of development.

\section{TABle II. Self-Fertilization in BALANUS PERFORATUS}

\begin{tabular}{|c|c|c|c|c|}
\hline & $\begin{array}{c}\text { Percentage } \\
\text { with } \\
\text { egg } \\
\text { masses }\end{array}$ & $\begin{array}{c}\text { Percentage } \\
\text { with eggs } \\
\text { at Stage } 9 \\
\text { or below }\end{array}$ & $\begin{array}{l}\text { Percentage } \\
\text { with eggs } \\
\text { at Stage Io, } \\
\text { II and I2 }\end{array}$ & $\begin{array}{c}\text { Percentage } \\
\text { with fully } \\
\text { developed } \\
\text { eggs }\end{array}$ \\
\hline Contiguous individuals & 66 & I4 & I5 & 37 \\
\hline $\begin{array}{l}\text { Individuals separated by more } \\
\text { than ro } \mathrm{cm}\end{array}$ & 67 & 33 & 12 & 21 \\
\hline
\end{tabular}

\section{Mechanism of Development of Eggs of isolated Individuals}

It is not possible to decide except by a cytological investigation whether the eggs in the mantle cavity of isolated individuals are fertilized or have been developed parthenogenetically. The abnormal development of the eggs in some instances suggests the possibility of parthenogenesis. On the other hand, the testes and ovaries are ripe simultaneously and the penis is suitably placed for self-fertilization by discharging spermatozoa into the mantle cavity. Both Chthamalus stellatus and Verruca stroemia, and probably Balanus perforatus, are normally cross-fertilizing; Chthamalus has frequently been observed to copulate both in the laboratory and in the sea. However, in those species in which the development of eggs in isolated individuals occurs at all, it appears to take place with such regularity that it can hardly be considered as an unnatural or exceptional mode of reproduction. Moreover, the process is probably of some value to at least two species, for isolated individuals of Chthamalus are by no means uncommon towards high tide mark, while in deep water isolated Verruca are often encountered. If the eggs of such individuals were developing parthenogenetically, however, a further process would be required subsequently to bring about duplication of the chromosomes. The simpler hypothesis is, therefore, that self-fertilization takes place.

The possibility that water-borne spermatozoa can effect fertilization at a considerable distance from their origin must also be considered. The spermatozoa of barnacles, unlike those of most other crustacea, are flagellated. Direct 
microscopic observations, as well as electron micrographs, show that there is very considerable variation morphologically within the group. Spermatozoa of Balanus balanoides, and probably of other species of the genus, are spindleshaped and very elongated; under the electron microscope there appears to be no difference between the extremities (Barnes \& Dainty, unpublished results). Spermatozoa of Chthamalus and Verruca, on the other hand, have a definite head and tail which are distinguishable even under the light microscope. The spermatozoa of barnacles are usually immobile in the seminal fluid, but have been observed to become extremely active, both in Balanus balanoides and Elminius modestus, either after being discharged through the penis into the mantle cavity of another individual or as a result of treatment with chelating agents such as ethylene diamine tetra-acetic acid (Crisp, unpublished observation; cf. Fujii, Utida \& Mizuno, I955). In the last two species the spermatozoa are not otherwise readily activated, though an occasional movement may sometimes be seen when they are mixed with sea water. In Verruca and Chthamalus, however, the spermatozoa more frequently show activity when squeezed from the seminal vesicles into sea water. This greater spontaneous activity of the spermatozoa in sea water of those species in which fertilization in isolated individuals has been shown to be common might suggest that waterborne spermatozoa are responsible. However, if this were so it would be expected that the incidence of fertilization in isolated individuals separated by more than $3-5 \mathrm{~cm}$, the distance reached by the extended penis, would be a function of the distance of isolation. This is not the case; the incidence is sometimes equal to that of individuals lying within $3 \mathrm{~cm}$ of each other, and sometimes lower. There is never any indication of a gradual reduction of the incidence of fertilization with increasing distance of isolation, such as would be expected if water-borne spermatozoa were responsible. This difference in the activity and morphology of the spermatozoa may, nevertheless, be related to the capacity for self-fertilization.

Further, oviposition normally takes place in barnacles as a result of the stimulus of copulation and does not occur when embryos are developing in the mantle cavity (Crisp \& Davies, I955). Eggs awaiting fertilization are therefore rarely, if ever, found in the mantle cavity of cross-fertilizing species, nor have they been observed during the examination of many egg masses of Chthamalus, Verruca and Balanus perforatus. Similarly, seminal fluid in most species is emitted only as a result of stimulation during copulation; it is only rarely discharged directly into the water. When it comes in contact with sea water the seminal fluid usually coagulates and is dispersed only with difficulty. Water-borne insemination therefore appears most improbable since it requires that two processes (unstimulated oviposition and unstimulated seminal discharge), which on present evidence very seldom occur in nature, should occur simultaneously. The mechanism can be considered feasible only on the assumption that the barnacle acting as a female collects spermatozoa in sufficient 
quantity to provide an oviposition stimulus. The apparent oviposition and development of eggs in the mantle cavity of individuals which have not been immersed in water for long periods shows that water-borne spermatozoa are not essential.

If in these species self-fertilization accounts for the fecundity of isolated specimens, it is pertinent to inquire what is the stimulus leading to oviposition when it is not provided by copulation. In Chthamalus the ovaries give rise to a succession of broods, and should oviposition be held back because the barnacle is not suitably stimulated by insemination the ovaries may become very full of ripe eggs. It is possible that under these conditions the threshold of the oviposition stimulus becomes so reduced that movements of the barnacle's own penis in the mantle cavity are sufficient to cause eggs to be released, and seminal fluid is then simultaneously discharged.

If the continued ripeness of the ovary were the stimulus leading to selffertilization, one would expect the process to be more in evidence where the species was growing rapidly and had abundant food supplies. Individuals kept out of water for long periods, or those growing in unfavourable environments, would not be so likely to self-fertilize as isolated specimens on rocky coasts. The environment at New Brighton is sheltered, silty and unfavourable to the species, whereas it thrives on the exposed west shores of Anglesey and Caernarvonshire (Crisp \& Knight-Jones, 1954). The greater readiness with which self-fertilization occurs in the latter area at Aberffraw and Black Rock compared with New Brighton might therefore be explained in terms of nutrition. Similarly, in the earlier part of the summer more planktonic food would probably be available and the lower temperatures would cause basal metabolism to make less call on food reserves; hence self-fertilization might occur more readily at this season than later on, when reserves are becoming spent.

\section{SUMMARY}

I. Isolated individuals of Chthamalus stellatus, Verruca stroemia and Balanus perforatus often carry apparently fertilized egg masses. Fertilization by water-borne spermatozoa seems improbable because spermatozoa are not normally shed into the water by barnacles, nor are unfertilized eggs usually present in the mantle cavity except during copulation. Either self-fertilization or parthenogenesis must therefore be assumed to have taken place.

2. Eggs found in isolated individuals are often less viable than normal eggs. Nevertheless, they are sometimes capable of full development, and hatch to give swimming nauplius larvae.

3. The percentage of normal embryos is significantly less in egg masses of isolated individuals, than in egg masses of contiguous individuals.

4. Oviposition can probably occur in Chthamalus stellatus while it is out of water. 
5. There is some evidence that self-fertilization takes place more readily in C. stellatus when external conditions are most suitable for breeding. Selffertilization might therefore be ascribed to a lowering of the threshold of the oviposition stimulus resulting from the continued presence of mature eggs in the ovary.

\section{REFERENCES}

BARnes, H. \& Barnes, M., I954. The general biology of Balanus balanus (L.) da Costa. Oikos, Vol. 5, pp. 63-76.

CRISP, D. J., 1950. Breeding and distribution in Chthamalus stellatus. Nature, Lond., Vol. I66, pp. 3I I.

- 1954. The breeding of Balanus porcatus in the Irish Sea. F. mar. biol. Ass. U.K., Vol. 33, pp. 473-94. 1956. The spread of Elminius modestus in North West Europe (in preparation).

CRISP, D. J. \& DAVIES, P. A., I955. Observations in vivo on the breeding of Elminius modestus grown on glass slides. F. mar. biol. Ass. U.K., Vol. 34, pp. 357-80.

CRISP, D. J. \& KNIGHT-Jones, E. W., I954. Discontinuities in the distribution of shore animals in North Wales. Bardsey Observatory Report, I954, pp. 29-34.

Darwin, C., I854. A Monograph on the Sub-class Cirripedia: Balanidae, Verrucidae, etc. 684 pp. London: Ray Society.

FujII, T., UTIDA, S. \& Mizuno, T., I955. Reaction of starfish spermatozoa to histidine and certain other substances considered in relation to zinc. Nature, Lond., Vol. I76, p. 1068.

SOUTHWARD, A. J. \& CRISP, D. J., I956. Fluctuations in the distribution and abundance of intertidal barnacles. F. mar. biol. Ass. U.K., Vol. 35, pp. 2 II-29. 